NBER WORKING PAPER SERIES

AGGLOMERATION BENEFITS AND LOCATION CHOICE: EVIDENCE FROM

JAPANESE MANUFACTURING

INVESTMENT IN THE UNITED STATES

Keith Head

John Ries

Deborah Swenson

Working Paper No. 4767

NATIONAL BUREAU OF ECONOMIC RESEARCH

1050 Massachusetts Avenue

Cambridge, MA 02138

June 1994

This paper is part of NBER's research program in International Trade and Investment. Any opinions expressed are those of the authors and not those of the National Bureau of Economic Research. 
NBER Working Paper \#4767

June 1994

\title{
AGGLOMERATION BENEFITS AND \\ LOCATION CHOICE: EVIDENCE FROM \\ JAPANESE MANUFACTURING \\ INVESTMENT IN THE UNTTED STATES
}

\begin{abstract}
Recent theories of economic geography suggest that firms in the same industry may be drawn to the same locations because proximity generates positive externalities or "agglomeration effects." Under this view, chance events and government inducements can have a lasting influence on the geographical pattern of manufacturing. However, most evidence on the causes and magnitude of industry localization has been based on stories, rather than statistics. This paper examines the location choices of 751 Japanese manufacturing plants built in the U.S. since 1980. Conditional logit estimates support the hypothesis that industry-level agglomeration benefits play an important role in location decisions.

Keith Head

Faculty of Commerce

University of British Columbia

2053 Main Mall

Vancouver, BC V6T $1 Z 2$

CANADA

John Ries

Faculty of Commerce

University of British Columbia 2053 Main Mall

Vancouver, BC V6T $1 Z 2$

CANADA
\end{abstract}

Deborah Swenson

Department of Economics

University of California

Davis, CA 95616

and NBER 


\section{INTRODUCTION}

Firms in the sanie industry tend to cluster in particular regions. While this observation is not novel, it has become the basis for a number of recent formal models. Economists have proposed agglomeration effects in the form of both pecuniary and technological exteraalities

to explain industry localization. However, empirical work in this area has yet to establish the pervasiveness of externalities based on geographical proximity. Furthermore, we have little idea of the distances over which such effects operate. The recent infux of hundreds of new manufacturing plants from Japan into the U.S. provides a unique opporturity to study the location decision. It also raises the new issue of whether agglomeration effects, to the extent that they exist, operate on a mationality-specific basis.

Empiricul information on these issues is particularly important for the design of policies aimed at attracting manufacturing investment. For instance, if agglomeration is at least partly nationality-specific, a locality with a sparse U.S. manufactuing base might find it easier to develop its manufacturiug sector by attracting foreign affiliates than by attracting U.S. investment. Moreover, the existence of agglomeration externalities that spill across official borders will alter the payoffs of local goverunents competing for investment.

This paper estimates a location choice model using data on Japanese investors who established new manufacturing plants in the United States. We find that the Japanese ventures do not simply mimic the geographical pattern of U.S. establishments in their industry. Instesd, initial investments by Japanese firms spur subsequent investors in the same industry or industrial group to select the sarne states. We argue that this pattern of location choice supports an agglomeration-externalities theory of industry localization rather than a theory based on interstate differences in endowments of natural resources, labour, and infrastructure. Moreover, we find that the geographic extent of manufacturing agglomeration does not end at state borders; 
the attractiveness of a state increases with the level of industrial activity in neighbouring states.

Theoretical analysis has developed various explanations for manufacturing agglomeration. The early work of Marshall (1920) provides three compelling reasons for spatially concentrated industries: Localization provides a pooled market for workers with specialized skills, facilitates the development of specialized inputs and services, and enables firms to benefit from technological spillovers. Recent papers by David and Rosenbloom (1990) and Krugman (1991a, 1991b) have constructed formal models to analyze and extend these concepts.

There have becn few empirical studics of agglomeration effects. H rson (1986) examines data for the United States and Brazil and finds strong evidence that industry localization raises factor productivity. Glaeser et al (1992) do not find a positive relationship between industry concentration and city employment growth. Instead, they attribute city growth to industry diversity and competition. They posit that the lack of dynamic agglomeration effecta may arise because their sample consists of nature industries.

Previous studies of the investment location decision generally use a measure of aggregate manufacturing activity as an explanatory variable. Recent studies of this type include Wheeler and Mody (1992), Woodward (1992), Coughlin et al (1991), and Schmenner et al (1987). They find that firms are drawn to regions with heavy manufacturing activity. The few studies of industry-level location choice have focused on a limited set of industries. Cariton's (1983) study of domestic firms and Luger and Shetty's (1985) study of foreign frms find evidence of industry-level effects in three specific industries. Smith and Florids (1992) atudy the inveatments of Japanese auto-related parts suppliers and show that they tend to locate near Japanese assembly plants and prefer areas with greater aggregate manufacturing activity. Paat studies do not . quately distinguish between endowment and industry-level agglomeration effects. Manufacturing activity is likely to be correlated with a number of unmeasured factors favourable to 
specific locations: tlius. the coefficient ineasuring the attractive power of manufacturing activity partly captures the effect of unobserved endowments.

This study contributes to understandiug industry agglomeration in a number ways. We explicitly account for state-specific effects (including overall manufacturing activity) by employing state-specific constants. This slould capture a number of sources of unobserved variation between states. Our study comprises investments in 225 different 4-digit manufacturing industries. For each investment, the geograplical pattern of U.S. establishments in its industry serves as a control for industry-specific location factors. We argue that Japanese deviations from this pactern suggest agglomeration effects. In addition we examine whether members of Japanese industrial groups-knowu as keiretsu-tend to cluster geographically. Since these affiliations often involve the subcontracting of cornponents and other less tangible ties, a tendency for their members to cluster would offer additional evidence of agglomeration. Finally, we allow the attractiveness of a state to depend on its own industry clusters as well as those in bordering states.

The organization of the paper is as follows. Section II presents several theoretical accounts of agglomeration externalities and the altemative theory that we refer to as endowment-driven localization. Scction III describes our rescarch design, the main hypothesis we test and alternative hypotheses we consider. Section IV discusses the data set and the construction of agglomeration measures. Presentation of econometric results follows in Section V. This section employs a simulation to assess the strength of the estimated agglomeration effects. We conclude with a summary of the major results and a discussion of their potential policy implications. 


\section{THEORIES OF LOCALIZATION}

Localization, the geographic concentration of particular industries, could arise through a variety of mechanisms. The general category we are interested in, agglomeration effects, includes all economies that are an increasing function of the number of nearby firms. The cumulative location choices that constitute the process of agglomeration allow accidents of history to influence the long-run geographical pattern of industry. Local expansion of a sector sows the seeds for furtber expansion by increasing the supply of the factor that made the location attractive in the first place, rather than simply bidding up the price of a given stock. Theoretical attempts to formalize agglomeration effects have focused on three mechanisms that would yield such positive feedback loops: inter-firm technological spillovers, specialized labor, and intermediate inputs.

The vague and general concept of teclinological spillovers is probably the most frequently invoked source of agglomeration effects. Useful technical information seems to flow between entrepreneurs, designers, and engineers in a variety of industries. A large part of the spillovers between foreign-owned firms may include the flow of experience-based knowledge on how to operate efficiently in a given state.' Physical proximity may enhance kiowledge flows by making casual communication less costly. Since technological spillovers are usually impossible to measure, we know little about the geographical extent of these spillovers, the degree to which they operate within industries versus between industries, and the extent to which they fow between firms of different national origins. While the prosperity of the bigh-technology cluster in Silicon Valley and the high-fashion cluster in Milan may arise from local knowledge spillovera, less ephemeral stories involving specialized labour and parts may play equally important roles.

As indicated by Marshall, localized industry creates a pooled market for workers with spe-

\footnotetext{
'Examples of such information would iuclude experiences with meeting local government regulation, adopting
to the local climate and labour force. and low-cost transportation options.
} 
cialized skills. This attracts workers for two reasons. First, as argued by David and Rosenbloom (1990), if the fortunes of individual firms are not perfectly correlated, the spatial concentration of industry is advantageous to laid-off workers who will be able to find new jobs with other firms. Hence, an increased number of firms reduces the likelihood that a worker will suffer a long bout of unemployment. This reduced risk will ultimately benefit the firms as well by increasing the supply of specialized labour and reducing the risk premium embodied in the wage. Rotemberg and Saloner (1990) propose what could be seen as a complementary effect. Workers in a given location will be more inclined to invest in industry-specific buman capital if they feel confident of their ability to appropriate the benefits. A monopsony situation might allow the employer to capture the benefits instead. Thus. by nitigating the bold-up problem, agglomeration generates the development of more industry-specific skills.

Krugman (1991b) argues that the combination of scale economies and moderate transportation costs will encourage the users and suppliers of intermediate inputs to cluster near each other. Such agglomerations reduce total transportation costs and generate large enough levels of demand to warrant efforts to produce highly specialized components. This will attract assemblers which in turn encourages new arrivals and additional specialization.

The "just-in-time" inventory system employed by many Japanese manufacturer raises the total cost of transporting parts because it requires flexible and punctual deliveries. Due to the importance this system places on reliability and trust, it may also encourage specialization in the form of long-term relationships. These arguments suggest that agglomeration effects will exert a particularly strong influence on Japanese manufacturers as they attempt to transplant their production systems to North America.

While recent theoretical work bas concentrated on agglomeration models of industry localization, a simple alternative liypothesis, endowment-driven localization, draws on traditional 
trade theoly. The latter theory argues that industries will concentrate in regions with favorable factor endowments. For instance, sawmills might congregate in a particular state to take advantage of its abundant supply of high quality timber. A broad view of factor-endowments would include man-made inputs whose supply is not affected by the output of any particular industry.

In botb theories of localization, firms in the same industry cluster geographically; bowever, only in the presence of agglonieration externalities does the clustering add to the attractiveness of the location. For instance the existence of an immobile and exogenously supplied input would tend to attract investment from industries that use that input intensively. However, as frms congregate, the location becomes less attractive since competition among users bids up the price of the input. A corresponding phenomena could occur on the demand side if exogenous forces had promoted the concentration of downstream demand for a particular industry. These considerations suggest an inportant difference between the theorica: agglomeration benefits could result in two states with identical endowments receiving very different shares of the investment in any particular industry. This study will estimate the magnitude of industry-level agglomeration effects and assess their importance in location decisions.

\section{Research Design}

We model the location decision of Japanese manufacturing plants as a conditional logit problem where the dependent variable is the state chosen by each investor. Following the method employed in earlier studies such as Carlton (1983) and Bartik (1985), we exploit McFadden's (1974) result that logit choice probabilities may be derived from individual maximization decisions if unobserved heterogeneity takes the appropriate form. We asaume that each investor chooses the state that would yicld the bighest profit. Profits depend on the availability of inputs 
that enter in the firm's production function which include agglomeration effects sternming from nearby economic activity of similar firnss. Idiosyncratic shocks, denoted $\epsilon_{j,}$ also affect profito but they are not observed by the econometrician. As derived in the appendix, the profitability of state $s$ for investor $j$ niay be represented as

$$
\theta_{0}+\alpha_{\ell} s \ln A_{j o}^{U S}+\alpha_{J} \ln A_{j,}^{J}+\alpha_{G} \ln A_{j,}^{G}+\epsilon_{j,}
$$

where $\theta$, captures the attractiveness of state $s$ to the "average" (or representative) investor and $A_{j \rho}^{U S}, A_{j,}^{J}$ and $A_{j,}^{G}$ are agglomeration variables measured as counts of U.S., Japanese, and Group (keiretsu) establishnents. Each measure varies across investors, $j$, since investors differ by industry, keiretsu membership, and time of entry. The state effect reflects infrastructure, the prices of variable inputs such as labour, raw materials, and energy as well as any other atate characteristic important to the average Japanese investor.

McFadden (1074) demonstrated that if, and only if, $\epsilon_{j}$, is distributed as a Type I Extreme Value independent random variable the probability that state a will yield investor $j$ the higheat profits among all the states in choice set $\mathcal{S}$ is given by the logit expreasion,

$$
\operatorname{Pr}(j s)=\frac{\exp \left(\theta_{0}+\sum_{i \in A} \alpha_{i} \ln A_{j,}^{i}\right)}{\sum_{\ell \in S} \exp \left(\theta_{l}+\sum_{i \in A} \alpha_{i} \ln A_{j \ell}^{i}\right)}
$$

where $\mathcal{A}=\{U S, J, G\}$. Maximum likelihood techniques use these probsbilities to eatimate the state-specific constants and agglomeration coefficients.

Our use of state effects contrasts with the spproach taken by previous studies of location decisions in manufacturing in which the authors explicitly included state characteristics ouch as wages, unionization rates, energy prices, and access to a major port. ${ }^{2}$ The problem with

\footnotetext{
${ }^{2}$ Friedman et al (1992) is n receut example. It provides a tabular summary of results from previous work.
} 
that approach stems from the uear impossibility of selecting and correctly measuring all of the relevant infrastructure and input price information that affect location decisions. Omitted sources of attractiveness would almost certainly induce a correlation between the error term and the agglomeration variables. State effects can include influences on the location decision that are particularly difficult to measure, ranging from the strength of the work ethic in a particular state to the quality of its golf courses.

While $\theta$, captures the attractiveness of state $s$ to the average investor, unobserved characteristics of choosers can still inake some states closer substitutes in the eyes of certain investors. Suppose that the parametess of the production function vary across industries but are constant for investments in the same 4-digit industry. In this case, firms in industries with high factor intensities will choose states with abundant endowments of those factors. For priced inputs, low prices will indicate abundance. This suggests that indust 1y-level agglomeration variablea will be correlated with the unobserved factor conditions pertaining to that industry that constitute the error term in our model. With a large enough data set, featuring multiple investments in each industry, this problem could be resolved by including state-industry-specific constants. Bowever, since our sample of 751 investments includes plants in over 200 different 4-digit industries, this strategy is not feasible.

The use of a sample of new foreign investors-the Japanese influx during the 19809-provides an alternative strategy for separating agglomeration and endowment effects. The geographical distribution of U.S. establishments in a particular industry should incorporate all the relevant information on the abundance of endowments used intensively in that induatry. Significant drawing power of prior Japanese investment, after controlling for the U.S. pattern, should provide an indication of agglomeration effects.

The empirical investigation distinguishes between alternative explanations for Japanese locar 
tion patterns that deviate from those of U.S. firms in the same industry. In addition to Japanesespecific agglomeration effects, there are two primary explanations for distinctive Japanese patterns. The first is that Japanese firms cluster in the same states regardless of industry for fundamental reasons, i.e. Japanese investors might choose a state because they want to be on the Pacific coast, or in a low-unionization state or near major population centers. These effects would be captured by the state-specific constants. A second possibility is that Japanese investors concentrate by industry duc to systematic forms of heterogeneity that make particular locations intrinsically attractive for certain types of Japanese investment. For instance, if a subset of investors, such as auto firms, rely disproportionately on intermediate inputs, they would exhibit preference for states with superior transportation facilities. We atternpt to weed out such potential sources of uncontrolled-for inter-industry variation by testing the robustness of our formulation to deletions of particular regions from the choice set and industries from the investor set.

\section{DATA}

The data employed in this paper come from a survey of Japanese manufacturiag investments in the United States conducted by the Japan Economic Institute. For each plant in the sample we know the year it began operations, the identity of the parent firm or firms, and the products it manufactures. Since most policy discussion focuses on efforts to attract new (also known as "greenfield") investments. we excluded acquisitions from the sample. ${ }^{3}$

Our estimation includes investments that began operations after 1979. The previous investments are used to form the Japanese agglomeration levels as of the beginning of 1980 . The

\footnotetext{
${ }^{3}$ The location model for new investment probubly differs in important waye from the model for acquinitions. Since acquisitions involve changes in owuership rather then the creation of new eatablithments, they bave ambiguour effects on our aggloweration mensures. Furthermore, while new ventares may locate wherever they went, acquirors are limited to the current locatious of potential targets.
} 
smaller estimation window reduces potential variation in rclative infrastructure levels and factor prices. Also, since the character of Japanese direct investment may have changed over time, this reduces unobserved heterogeneity. Finally, the use of the later data allows for a closer match with our U.S. data which was drawn from the 1982 and 1987 censuses. The post-1979 sample contains over $80 \%$ of Japanese manufacturing investments in the United States.

Figure 1 depicts the geographical patteru of all greenfield Japanese investment. Below each value for Japanese investment we give the percentage of U.S. establishments in that state in 1982. Since the U.S. sample is constructed from the same set of 4-digit industries as the Japanese sample, we would expect the upper and lower numbers to match very closely if there were no special influences on the location of Japanese investment.

A number of states received no Japanese investment at all. The data in Figure 1 reveals that those states-namely Delaware. Idalıo, Montana, New Mexico, North and South Dakota, Rhode Island and Wyoming-are quite unpopular with U.S. manufacturers as well. Conditional logit requires that all choices be selected at least once. Consequently we removed those states from the choice set. We further reduced the choice set by removing statcs (Hawaii, Louiaiana, Maine, Minnesota. New Hampshire, Utah, Vermont and West Virginia) which received fewer than 3 investments after 1979. This reduces the number of estimated parameters by 8 while reducing the sample by only 9 observations. Given the independence from irrelevant alternatives assumption built into the logit specification, the reduction in the choice set should not affect the other parameter estimates.

We estimate the effects of four types of agglomeration variables on the location choice. In each case agglomeration is measured as a count of establishments the year before the venture began operations. We selected establishr $t$ counts, rather than production or employment levels, 
Figure 1: The Geographical Distribution of Japanese and U.S. Manufacturing Establislımeots*

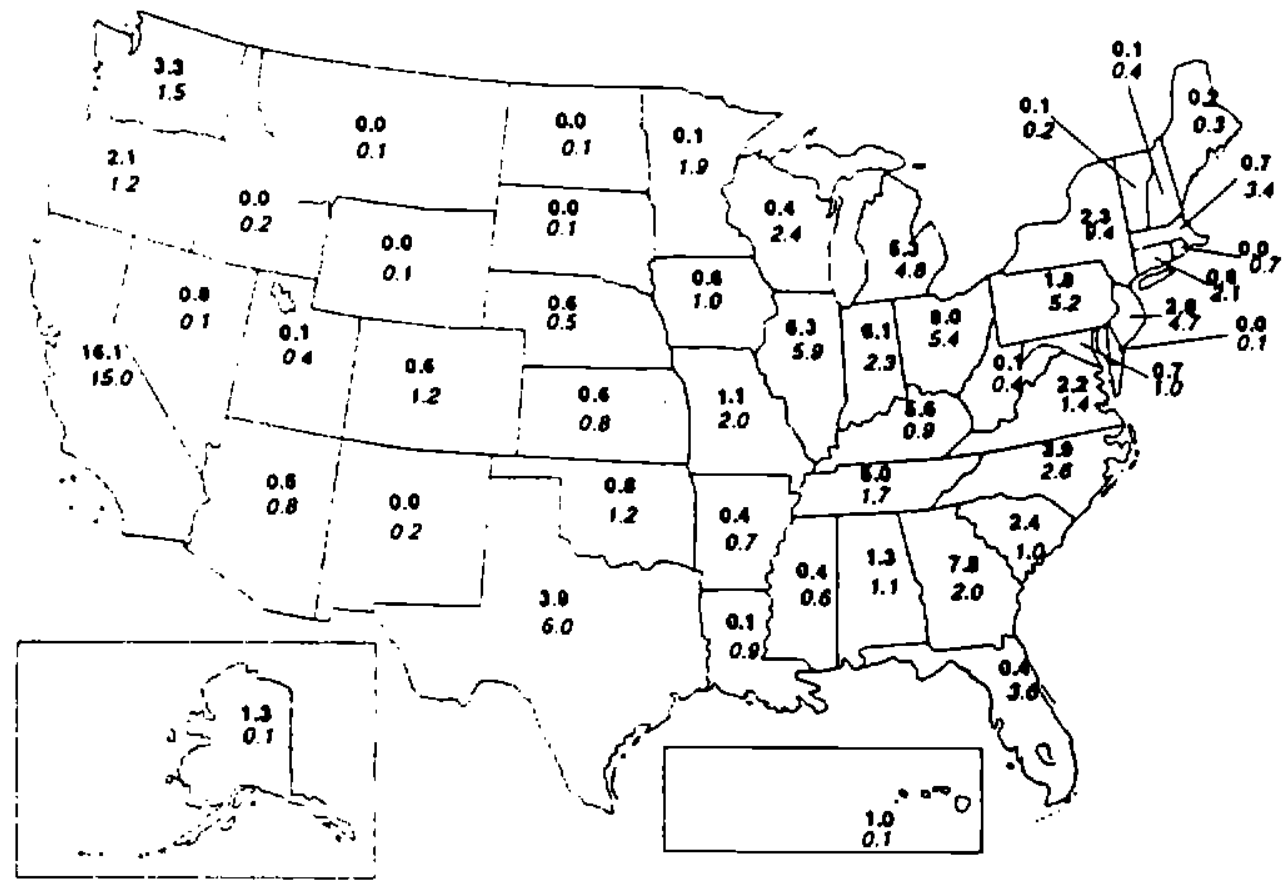

*: Figures expressed as percentages of the Japan total of 900 greenfield inveatmeats and the U.S. totel 1982 atock of 229,292 araufacturiag estnblishanents. U.S. figures beeed on 1982 Census of Manufacturiag Data for all 4-digit SIC iudustries that received some grecufield Japniese iuvestmeat.

because that allowed us to construct equivalent measures of Japanese and U.S. agglomeration.4

The following list defines the four types of agglomeration effects investigated in this study.

U.S. activity: $A_{y,}^{U S}$ Number of establishments in same 4-digit SIC. Investments that began operations between 1980 and 1984 (inclusive) are matched to 1982 Census of Manufacturing counts. Later investments are matched to the 1987 Census.

'Date confidentiality in the U.S. Census of Manufacturing reaulth in eatablishmente being the oaly variable which is available for every atate in every 4-digit SIC industry. There is a elight difference between the Japanese and U.S. establishment counts. The U.S. dats puts each extablinhenent in ose indurtry. We have dale on multiproduct Japasese plants which does not indicate the primary SIC of the plant. It coeme reanonable that a 450 producing two products would care sbout the activity in both industries in each state. Bence, we count oach product line a a ceparate plant for enlculating the relevant agglomeration varibles. Note, however, that we model unulti-product plawts as siugle choosers in the eatimation. 
Japan-based activity $A_{j,}^{J}$ Number of plants operating in same 4-digit SIC in the year before investment $j$ began operations. Source: Japan Economic Institule 1990 Updated Survey.

Industrial Group member activity $A_{j s}^{G}$ Number of establishments in same manufacturerled Reiretsu. Group affiliations were compiled using Kigyo Keiretsu Soran, a publication of Toyo Keizai.

Border-State Activity: $\sum_{\ell \in \mathcal{B}(s)} A_{\ell}^{i}$ where $i=U S, J, G . B(s)$ is the set of states with borders on state $s$.

The two industry-level agglomeration variables $\left(A^{U S}\right.$ and $\left.A^{J}\right)$ make use of the standard industrial classification tables. We employ the relatively detailed 4-digit level of disaggregation. These "industries" frequently lump disparate activities together but they may also separate closely related industries. We have found several cases where the use of standard classifications causes an understatenent of Japanese industrial concentration. For instance, Japanese firms made 41 investments in industry 3089, "plastic parts, not elsewhere classified" However, 22 of those plants produced plastic parts for automobiles. Of the remaining 19 plants, $32 \%$ selected Georgia compared to $2 \%$ of all U.S. establishinents in industry 3089. Machine tools provides a case where insufficient aggregation hides the extent of agglomeration. Five of thirteen Japanese makers of machine tools for metal cutting (SIC 3541), two of six makers of cutting tools (SIC 3545), and four of five makers of the numerical controls used for machine tools (SIC 3625) cbooe minois. While Ilinois is relatively strong in each industry, it accounts for little more than $10 \%$ of the U.S. establishments in these industriea.

The last two sources of agglomeration effects, industrial groupe and activities in borderstates require some additional explanation. With respect to $A^{G}$, we consider only induatrial or -vertical" groups; i.e. those headed by large manufacturing companies whose members consist 
largely of coniponent suppliers. Vertical linkages are likely to be strong in these groups which may motivate them to locate close to eacls other in order to access supplies and facilitate information exchange. We exclude bank-centered or "horizontal" groups which are largely defined by financial linkages and tend to beliave inore like diversified conglomerates. Since state borders are rather arbitrary boundaries for the extent of agglomeration effects, we created border-state variants of $A^{t s}, A^{J}$, and $A^{G}$ by summing the number of firms in adjacent states. These variables allow for the possibility that, for example, Indiana is attractive to widget manufacturers not only because of the widget produccrs there but also because of widget producers in Ilinois. Ohio, Michigan and Kentucky.

\section{RESULTS}

Table 1 presents the aggloneration coefficients generated by maximum likelibood estimation of equation (2). The estimation included state-specific constants which we omitted from the results table. Column (1) provides the benchnark model estimates where we test whether Japanese ventures emulate their American counterparts. This specification describes location choice when country-of-origin effects are absent or the case where the number of U.S. firms acts as a proxy for industry-specific endowment effects. The estimated coefficient reveals that Japanese firms locate in regions where there are a relatively large number of U.S. establishments in the same industry. If the error term is an independently drawn disturbance, the coefficient on $\ln A^{U S}$ measures the impact of agglomeration on location choice. However, the endowment theory of localization (described in Section II) Buggests that the error term, $\epsilon_{j o}$ in equation (1), will be correlated with $A^{U S}$, in which case the coefficient on $\ln A^{U S}$ will reflect endowment effects in addition to agglomeration economies.

Columns (2) and (3) reveal a "follow-the-leader" pattern of Japanese investment that is 
Table 1: Agglomeration Effects on Location Choice

\begin{tabular}{|c|c|c|c|c|c|}
\hline & \multicolumn{5}{|c|}{ Dependent Variable: Location Choice } \\
\hline & (1) & (2) & (3) & (4) & (5) \\
\hline $\ln A_{s}^{U S}$ & $\begin{array}{c}0.600 \\
(0.060)\end{array}$ & $\begin{array}{c}0.505 \\
(0.060)\end{array}$ & $\begin{array}{c}0.502 \\
(0.060)\end{array}$ & $\begin{array}{c}0.490 \\
(0.060)\end{array}$ & $\begin{array}{c}0.476 \\
(0.061)\end{array}$ \\
\hline $\ln \sum_{\ell \in B(s)} A_{\ell}^{\ell S}$ & $\begin{array}{c}0.286 \\
(0.071)\end{array}$ & $\begin{array}{c}0.218 \\
(0.070)\end{array}$ & $\begin{array}{c}0.216 \\
(0.070)\end{array}$ & $\begin{array}{c}0.233 \\
(0.070)\end{array}$ & $\begin{array}{c}0.243 \\
(0.071)\end{array}$ \\
\hline $\ln A_{s}^{J}$ & & $\begin{array}{c}0.607 \\
(0.092)\end{array}$ & $\begin{array}{c}0.603 \\
(0.094)\end{array}$ & $\begin{array}{c}0.591 \\
(0.095)\end{array}$ & $\begin{array}{c}0.592 \\
(0.095)\end{array}$ \\
\hline $\ln \sum_{\ell \in B(s)} A_{\ell}^{J}$ & & $\begin{array}{c}0.449 \\
(0.093)\end{array}$ & $\begin{array}{c}0.405 \\
(0.094)\end{array}$ & $\begin{array}{c}0.362 \\
(0.096)\end{array}$ & $\begin{array}{c}0.363 \\
(0.096)\end{array}$ \\
\hline $\ln A_{s}^{G}$ & & & $\begin{array}{c}0.768 \\
(0.131)\end{array}$ & $\begin{array}{c}0.749 \\
(0.131)\end{array}$ & $\begin{array}{c}0.749 \\
(0.131)\end{array}$ \\
\hline $\ln \sum_{l \in B(s)} A_{l}^{G}$ & & & $\begin{array}{c}0.342 \\
(0.140)\end{array}$ & $\begin{array}{c}0.301 \\
(0.143)\end{array}$ & $\begin{array}{c}0.301 \\
(0.143)\end{array}$ \\
\hline USGROWTH & & & & & $\begin{array}{c}0.110 \\
(0.085)\end{array}$ \\
\hline Log-Likelihood & -2173.39 & -2127.13 & -2108.82 & -2065.22 & -2064.38 \\
\hline No. of Choosers & 751 & 751 & 751 & 751 & 751 \\
\hline No. of Choices & 34 & 34 & 34 & 34 & 34 \\
\hline
\end{tabular}

Note: Conditional logit regreasions estimated by maximum likelihood. Swaderd erors is parentheses. Alternative apecific conatanto were employed in ach or. timation. Columns (1) and (5) were estimated with otsto-apecitic time treade a well. A, corresponds to atock of frme operating in atute on the beginaing of the year when the relevent venture's began operntions. It includen that venture. The superscript J, US, and $G$ refer to Japanese plants in tho ventures 4-digit SIC, US establishments in the 4-digit SIC, and plants at leat $50 \%$ owned by members of the parent company'o iaduetry group. $B(0)$ is the set of stales tbat border state s. Hence, the summation is the aggregale stock in adjacent stales. 
difficult to interpiet as anything other than agglomeration effects. The location of Japanese investments is significantly influenced by the locations of previous Japanese investments in the same industry and/or keiretsu. The larger coefficients on the Japanese agglomeration variables suggest that the attractive effect of prior Japanese investment exceeds that of prior U.S. investment. ${ }^{5}$ The large significant coefficient on $\ln A^{G}$ corroborates our hypothesis that supply relationships between Japanese firms and technological spillovers are stronger between members of the same industrial keiretsu.

Adding the Japanese industry and group counts significantly improves the explanstory power of the regression equation. The likelihood ratio test overwhelmingly rejects the bypothesis that the four Japan-specific variables (within-state and horder-state $A^{J}$ and $A^{G}$ ) have no explanatory power. Moreover, including these variables detracts little from the aignificance of the U.S. variables. The following reasons cause us to believe that the estimated coefficients reflect more than simple correlation between location decisions and unobserved state industry endownents. To hegin, we would expect the coefficients on the U.S. variables to capture this correlation. If the same unohservables were responsible for the estimated effect on Japanese counts, they would not result in the significant new information demonstrated by the likelihood ratio test. Moreover, we would expect the Japanese variables to share the measured effect of the U.S. variable in column (1) which they clearly do not.

We added the industrial group variable, $A^{G}$, in column (3) to determine whether vertical linkages might provide an additional impetus to Japanese frms' location decision beyond the draw of previous investments in the same industry. For example, a firm that produces plastic auto parts might be attracted to a state that has considerable auto production even if there were

\footnotetext{
'A likelihood ralio teat of the hypothesis that the U.S. and Japanese effecte (within-atate and bonder-atate) are equed rejeets at the 0.04 confidence level.

-The teat atatistic is 129 and the critical value for significance at the 0.005 level is 15.
} 
no concentration of plastic parts producers in that state. We also hypothesized that member firms might locate near each other to reap the benefits of shared information. Column (3) estimates show that group menber activity provides a strong attractive force for investment decisions.

We tested analogous agglomeration measures which indicated border-state industry activity by U.S. firms, Japanese firms. and keiretsu members in addition to the within-state agglomeration variables. The statistical significance of all three border-state variables indicate that agglomeration externalities cross state boundaries, although, as one might expect, the magnitude of the effect declines. While anecdotal accounts suggest that agglomeration benefits operate over small geographic areas such as cities, our results suggest that they extend over greater distances. A group of states becomes collectively more attractive through the activity of each of its members. creating an industrial "cluster" that could extend for hundreds of miles."

One potential problem for interpreting the effect of $A^{J}$ is that the Japanese ventures, for the most part, started more recently than the American ones. Because most Japanese investments occurred later. it is possible that relative levels of infrastructure or factor prices changed from those prevailing at the time U.S. firms made their location decisions. The apparent Japanese agglomeration might then arise solely as a response to the new conditions faced by the Japanese firms when they made theit investments. ${ }^{8}$

We allow for changes in the relative attractiveness of states by adding state-specific time trends. ${ }^{9}$ This makes the model robust to trends affecting the relative attractiveneas of state in the eyes of the average investor. Column (4) displays estimates of the agglomeration elasticitiea

\footnotetext{
'Bowever, border-ntate octivity is not always distent, at it may involve cities like St. Loais that otraddle state borders.

'Relocation costs might generate tbe inertia implied by U.S. firmo' decitious to remain in locations where eavironmental factors have becone unfavorable. However, agglomeration effects could be at work as well

'The appendix contaios a derivation of these time trends sbowing what forms of change they can eccomodete.
} 
when these state time trends are included. While a likelihood ratio test reveals that inclusion of the time trends adds significant explanatory power $(p-v a l u e=.005)$ to the specification, they do not affect the magnitude or the significance of the coefficients on the agglomeration variables. Therefore, although relative state attractiveness changed over the 1980 s, the measured Japanese agglomeration effects do more than reflect trends in the attractiveness of individual states.

To the extent that there are industry-specific effects, we need to provide a control for changes that make a state more attractive during the sample period for certain industries but not others. We employ a variable callcd USGROWTH which is the growth rate in the number of establishments in each industry-state between the 1982 and 1987 census. ${ }^{10}$ The inclusion of USGROWTH should sharply diminish the significance of the Japanese agglomeration if the latter variables simply reflect recent changes in industry-specific endowment effects. As shown in column (5), USGROWTH does not have a significant effect on location choice and its presence has a negligible effect on the coefficients of the agglomeration variables.

\section{V-A Interpretation of Coefficients}

Interpreting the magnitude of the coefficient estimates is not straightforward in the logit model. The ratios of the coefficients correspond to the ratios of parameters in the underlying production function. Thus, in column (3), the elasticity of output with respect to border-atate asglomerztion ranges between $43 \%$ and $67 \%$ of the elasticity with respect to within-atate agglomeration. The question remains whether the within-state agglomeration effects $-0.50,0.60$, and $0.77-$ are "large" numbers. One way to assess their magnitude is to express them as average probability elasticities. The elasticity of the probability of a particular investor $j$ choosing atate $\bullet$ with

\footnotetext{
${ }^{10}$ Defiaitions of industries changed in 1987 . To male the 1982 and 1987 series compatible, we created componite industry definitions. For instance, 1977 SICs 2651 and 2654 became aither SIC 2656 or 2657 uader the 1087 classification system. For this case, ree created a composite induatry that is the sum of 2651 and 2654 for 1082 and the sum of 2656 and 2657 for 1987. USGROVITH measure the growth rate of that composite indurtry.
} 
respect to agglomeration variable $A^{i}$ can be calculated by differentiating equation (2).

$$
E_{j s}^{i}=\frac{\partial \operatorname{Pr}(j s)}{\partial A^{i}} \frac{A^{i}}{\operatorname{Pr}(j s)}=\hat{\alpha}_{i}(1-\operatorname{Pr}(j s))
$$

Summing over all clioosers $(j)$ and clioices $(s)$ we obtain the relationship between average probability elasticities and the coefficient estinate, $\hat{\alpha}_{i}$.

$$
E^{i}=\sum_{j=1}^{N} \sum_{j=1}^{S} E_{j,}^{i}=\alpha_{i} \frac{S-1}{S}
$$

Since $S$, the number of choices. equals 34 in the estimations, elasticities can be obtained by multiplying the estimated coefficient by 0.97 . The average probability elasticities indicate that for the average state increasing its stock of establishments in some industry by $10 \%$ would increase its likelihood of being chosen by a subsequent investor in that industry by $5 \%$ to $6 \%$. Adding the very first Japanese plant in an industry raises the attractivenesg of that state to other firms in the industry by $50 \%$.

Thus far, we have shown that the coefficients we interpret as agglomeration effects are very signficant statistically and that agglomeration appears to increase the attractiveness of a location by a respectable percentage. However, we have not answered the question which should be of great concern to policy makers: If financial incentives succeed in attracting an initial investment, will that set in motion cumulative effects that will be strong enough to have a substantial impact on the location choices of subsequent investments? To eddress this question, we used the estimated coefficients to simulate the consequences of state actions that attract investments.

Our simulation considers an bypothetical "representative" industry that initially has no Japanese investment and a 1000 U.S. establishments distributed acros states in proportions 
equal to those of tise aggregate U.S. manufacturing sector (as portrayed in Figure 1). The simulation entails the sequential entry of 30 Japanese plants. Each one chooses a location based on state characteristics (including location decisions of previous investments) and a Type I Extreme Value independent random shock. This gives rise to a baseline allocation of investments ecross states. We compare this baseline to an alternative scenario in which the simulation assigns the first plant to a predetermined state and allows the following 29 investments to choose states in response to the exact sasne pattern of disturbance terms. This allows us to measure the long run impact for each state of attiacting the frst investment. We repeat the experiment 100 times and compute the average outcome.

Figure 2: The Long Run Payoff From Attracting an Initial Investment*

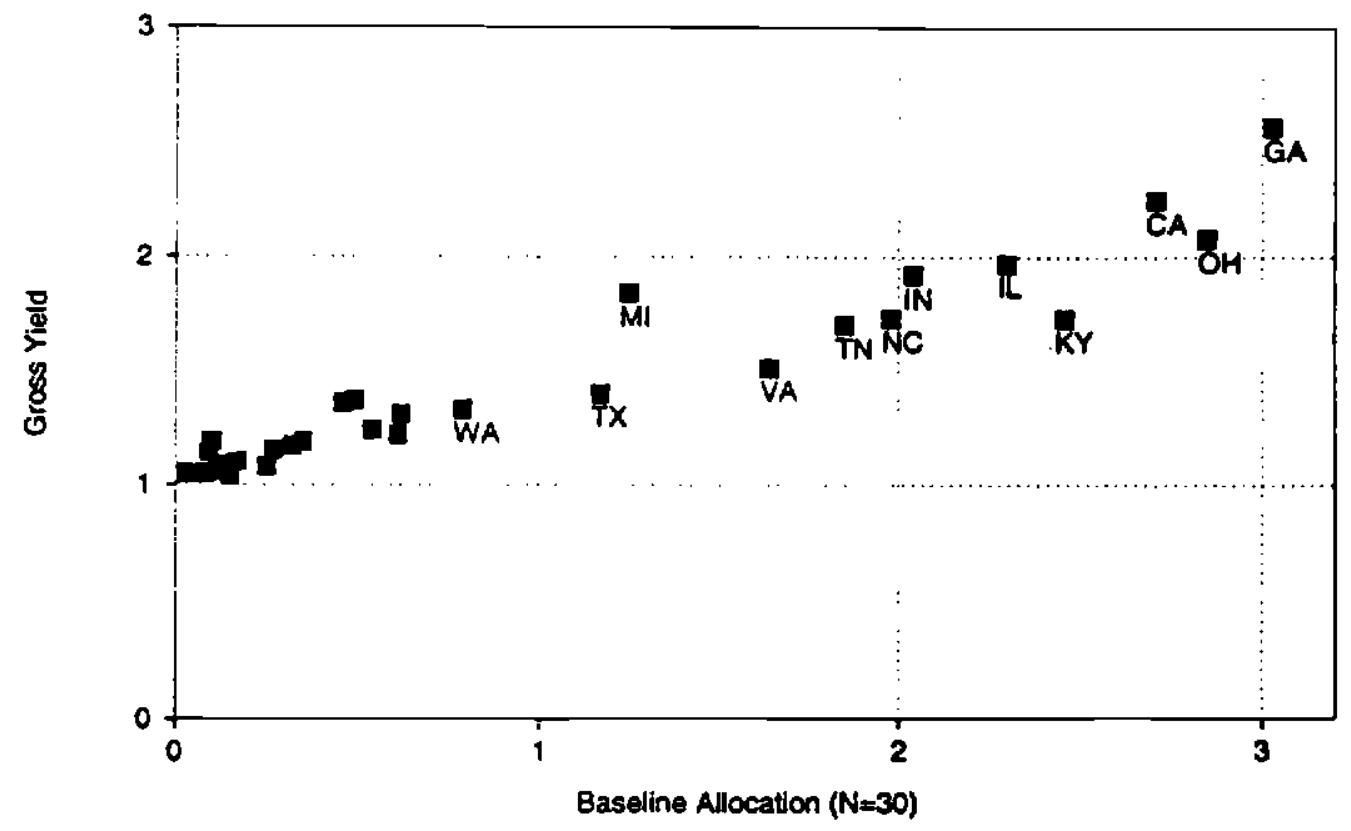

-: The $X$-exie showa the everage number (across 100 meparate aimulation run) of inventments that cach atate attrects. The $Y$-exis thows the average inerease in inveatments attracted if the fint investment were argigned to the state in question.

Figure 2 depicts the distribution of the 30 Japanese investments both in the presence and 
absence of state policies securing initial investments. The horizontal axis measures the number of investments in each state in the "baseline" case where the Japanese plants locate based on the state characteristics and a random error term. The vertical axis shows the gross investment yield of actions that ensure the first investor locates in a particular state. The gross yield includes the first investment plus any changes in subsequent location decisions resulting from assigning this investment to the state in question. ${ }^{11}$ The figure indicates that states with manufacturing concentrations or estimated "desirable" state-specific effects such as Georgia, Ohio, and California attract the inost investment, an average of about three investments each. Moreover. these states also receive the the highest gross yields. While the simulation reveals that state policies that attract initial investments usually lead to further investment in that state, subsequent investment related to agglomeration is fairly limited. Across the 34 states we consider, the gross yield on policies ensuring that the first of 30 Japanese investors locate a particular state is only 1.4 investments. For "attractive" states, the payoff is higher-2.57 for Georgia and 2.25 for California. Over the 100 trials, these states occasionally gained as many as 8 or 10 investments. On the other hand for "unattractive" states, attracting the initial investor yielded little beyond that particular investment.

\section{V-B Robustness Issues}

Conditional logit estimation relies on the assumption of identical independent error termo in equation (1). If these assumptions are not met in the data, a violation of the independence of irrelevant alternatives (IIA) property will lead to biased estimates. ${ }^{12}$ The inclusion of alternative-

\footnotetext{
I'In wome trials, the grow yield for a particular atute was zero or even pegative. There vere trials where the initial investment located in the atate in quetion in the beceline cave wo the mercies yielded no net change. In otber trials relocating the first investment alters ensuing contests for investment wuch that the atale's competition for certain investments is made stronger and the atate no longer altracts the inveatments that it did in the baseline ease.

${ }^{13}$ The IIA property, which is necessary for unbiased conditional logit estimation, implies that the relative probebility of cboosing two alseruative (states) does not depead on the avilability or characteriatica of other
} 
specific constant terms (state dumuny variables) removes some forms of bias that might arise. Train (1984, p. 18-25) shows that adding alternative-specific constant terms-8tate effects in this study-allows for the use of a conditional logit specification in the presence of some forms of IIA violation. Specifically, our model is valid as long as investors bave uniform perceptions of the substitutability between states. However, unobserved characteristics of the choosers might make some choices closer substitutes in the eyes of certain investors than other choices. Such unobserved heterogeneity will lead to a violation of ILA. ${ }^{13}$ Consequently, the coefficient estimates will depend critically on the sasnple of choosers and choices. To investigate whether our results are robust, we reestimate the model using a variety of sub-samples, where each sub-sample is chosen to remove a potential violation of the independence assumption. We find that the coefficients on the parameters of primay interest remain remarkably stable.

We selected four groups of states to remove from the sample: the Pacific, the Rust Belt, the Sun Belt, and the Soutl. In each of these regions, states might have certain characteristics in common that could lead to violations of the IIA assumption. Pacific states (Alaska, Washington, Oregon, and California) have lower transportation costs to Japan. Rust Belt states (Illinois, Lndiana, Obio, Michigan. Wisconsin, Pennsylvania, New Jersey, New York, Connecticut, Massachusetts, and Maryland) tend to have relatively high unionization rates and have a declining share of the nation's population. Sun Belt states (California, Arizona, Nevada, Texas, and Florida), on the other hand, bave experienced rapid population growth over the last decade. Southern states (Georgia, South Carolina, Mississippi, and Alabama) have low unionization rates and have enjoyed rapid growth of manufacturing. The IIA problem does not arise from

altersatives. For instance, in a choice between three states-A, B, and $C-\operatorname{Pr}(A) / \operatorname{Pr}(B)$ is independent of the charecteristica of atate C. Suppose, however, that in reality investorn uniformly riew ataken C and B a clove cubstitutes, while they regard A as substanilally inferior to either. An anobarved improvement in C rould increase $\operatorname{Pr}(A) / \operatorname{Pr}(B)$.

${ }^{13}$ Conditional probit models allow for corteluted exror terms. Bowever, they are computationally infeacible with such a large ent of choices. 
the regional differences by themselves. If low unionization raised the attractiveness of Southern states to all Japanese investurs, this effect would show up in the state-specific constants. Instead. the concern is that a subset of the investors have strong opposition (or attraction) to some characteristic comution to a group of states. Since we generally cannot observe such sentiments, they will generate correlated error terus.

Table 2: Independence from Irrelevant Alternatives?

\begin{tabular}{|c|c|c|c|c|c|c|}
\hline & \multicolumn{6}{|c|}{ Dependent Variable: Location Choice } \\
\hline & No Pacific & No Rust & No Sun & No South & No Auto & No $F / W$ \\
\hline $\ln A_{9}^{l^{\prime} S}$ & $\begin{array}{c}0.460 \\
(0.069)\end{array}$ & $\begin{array}{c}0.383 \\
(0.070)\end{array}$ & $\begin{array}{c}0.469 \\
(0.066)\end{array}$ & $\begin{array}{c}0.595 \\
(0.066)\end{array}$ & $\begin{array}{c}0.508 \\
(0.068)\end{array}$ & $\begin{array}{c}0.455 \\
(0.062)\end{array}$ \\
\hline $\ln \sum_{l \in B(\Omega)} A_{l}^{l S}$ & $\begin{array}{c}0.300 \\
(0.097)\end{array}$ & $\begin{array}{c}0.164 \\
(0.081)\end{array}$ & $\begin{array}{c}0.383 \\
(0.093)\end{array}$ & $\begin{array}{c}0.179 \\
(0.072)\end{array}$ & $\begin{array}{c}0.218 \\
(0.077)\end{array}$ & $\begin{array}{c}0.227 \\
(0.073)\end{array}$ \\
\hline $\ln A^{J}$ & $\begin{array}{c}0.640 \\
(0.111)\end{array}$ & $\begin{array}{c}0.722 \\
(0.120)\end{array}$ & $\begin{array}{c}0.717 \\
(0.110)\end{array}$ & $\begin{array}{c}0.549 \\
(0.103)\end{array}$ & $\begin{array}{c}0.752 \\
(0.119)\end{array}$ & $\begin{array}{c}0.513 \\
(0.097)\end{array}$ \\
\hline $\ln \sum_{l \in B(\Omega)} A_{l}^{J}$ & $\begin{array}{c}0.248 \\
(0.105)\end{array}$ & $\begin{array}{c}0.438 \\
(0.123)\end{array}$ & $\begin{array}{c}0.310 \\
(0.108)\end{array}$ & $\begin{array}{c}0.440 \\
(0.101)\end{array}$ & $\begin{array}{c}0.340 \\
(0.123)\end{array}$ & $\begin{array}{c}0.407 \\
(0.094)\end{array}$ \\
\hline $\ln A_{s}^{G}$ & $\begin{array}{c}0.893 \\
(0.134)\end{array}$ & $\begin{array}{c}0.567 \\
(0.199)\end{array}$ & $\begin{array}{c}0.941 \\
(0.138)\end{array}$ & $\begin{array}{c}0.822 \\
(0.141)\end{array}$ & $\begin{array}{c}0.172 \\
(0.266)\end{array}$ & $\begin{array}{c}0.771 \\
(0.130)\end{array}$ \\
\hline $\ln \sum_{\ell \in B(\Omega)} A_{\ell}^{G}$ & $\begin{array}{c}0.145 \\
(0.155)\end{array}$ & $\begin{array}{c}0.525 \\
(0.189)\end{array}$ & $\begin{array}{c}0.232 \\
(0.160)\end{array}$ & $\begin{array}{c}0.419 \\
(0.152)\end{array}$ & $\begin{array}{c}0.604 \\
(0.237)\end{array}$ & $\begin{array}{c}0.339 \\
(0.140)\end{array}$ \\
\hline Log.Likelihood & .1668 .59 & -1121.45 & -1631.21 & .1733 .95 & -1490.59 & -2052.79 \\
\hline No. of Choosers & 609 & 462 & 612 & 654 & 518 & 729 \\
\hline No. of Choices & 30 & 23 & 29 & 30 & 34 & 33 \\
\hline
\end{tabular}

Nole: Conditional logit regreanions eatimated by maximum likalibood. Standard errors in parentbeace. Coefficienls for alteruative-apecific consteals are not reported Definition of RBS varibles cas be found in the note below Figure 1. "No Pacific" excludes AK, CA, OR, and WA. "No Rant" excludee CT, IL, IN, MA, MD, MI, OH, PA, NJ, NY, WI. "No Sun" acludee AZ, CA, RL, NV, TX. "No Soulh" excluder AL, GA, MS, SC. "Finb/Wood" refere to S1C. 2001, 2002, 2421, 2426 and 2436.

The results of estimating the model with the restricted samplea are shown in columns (1)-(4) 
in Table 2. The statistical significance and approximate magnitude of U.S. and Japanese withinstate industry-activity effects holds up well over four entirely different choice sets, although there is some variation in the estimates of the border-state effects. In particular, the withinstate agglomeration measures retain the same levels of statistical significance across the four 'samples. ${ }^{14}$ An alternative approach is to retain the full choice set while eliminating groups of similar investors. Columns (5) and (6) portray estimates after the elimination of ventures for which there are reasons to expect correlated error terms that will lead to violations of the IIA assumption: auto-related plants and plants involved in fish or timber processing.

Smith and Florida (1992) show that the location of large Japanese automobile assembly plants figured prominently in the location decisions of the over 200 subsequent investments by auto parts companies. While these clusters might indeed be partly attributable to Japanese agglomeration extemalities, they also could be a source of correlated errors among states with assembly plants. Column (5) shows the results of estimated the model after eliminating autorelated investments. ${ }^{15}$ Again, the results are generally robust to restriction of the sample. The within-state group variable does, however, become insignificant, suggenting that the eatimated keiretsu effect arises primarily from activity in the auto industry.

The last restricted sample eliminates two industries that draw heavily on local natural resources. Japanese firms processing canned and frozen fisb are heavily concentrated in Alaska whereas the corresponding U.S. industry was dispersed among various coastal states. Similarly, the concentration of Japanese lumber firms in Washington deviates from the U.S. industry pattern. We speculated that these Japanese ventures might be oriented towards exporting their

\footnotetext{
1"This approach to the IIA problem was inspired by formal test proposed in Bunamen and MeFadden (1984). We did not construct the test statistics because our uso of atternativo-specific conatents cansed the number of parameters to vary across specifications. Also, since their teats are only vilid under the maintained anomption of IIA in the restricted choice set. We felt that it would be more instructive to view the reduced-enmple entimation $\omega$ informal tests of robustaess.

${ }^{13}$ Auto parts investments span over forty \&-digit SIC codes. Bowever, the product deacriptione provided by the Japan Economic Institute generally make it clear which plants serve the auto iaduatry.
} 
products back to Japan. This unobserved intention could lead to correlated errors terms amor. states chosen by firms in these industries. Column (6) shows the result of eliminating ventures in canned and frozen fish and lumber industries from the sample. While the estimated coeffcients on the within-state U.S. and Japanese counts fall somewhat, all the effects remain positive and significant. ${ }^{16}$

The coefficient estimates presented in Table 2 demonstrate that our primary results continue to hold, regardless of the imposed sample restrictions. Both U.S. and Japanese within-state manufacturing activity attract Japanese investment in the same industry. the most part, border activity also appears to be an attracting force. The group activity results, however. appear less robust to changes in the sample. In particular, they seem to disappear altogether with the removal of the auto-related investments. This finding could reflect the limitation of using group affiliation to represent vertical linkages for groups other than those headed by automobile producers. While firms in auto groups almost certainly produce related products. other group affiliations might be among firms who produce completely different products. For example, in the case of electronics, many group companies were created as spinofis into new product lines and they have few actual business dealings with other group membera. ${ }^{27}$ The insignificance of group agglomeration in the non-auto sample also indicates that group companies may not need to locate foreign affiliates close to each other in order to facilitate information exchange.

\footnotetext{
"The tect that 9 out of 12 Japapese wood-products mapulacturers chose Wahington or North Caroline is hard to reconcile with a resourcedriven story given that Oregon and Virginie, which have large counts of U.S. ettablisbmeats, recejved no Japanese investment. However, we wanted to make oure that this highly concentraled inductry was aot driving our sesults.

${ }^{17}$ See Gerlach (1993). A case in point is Fanue which produces numerically controlled machine toole which differ substantially from the products of other members of the Fujitsu croup.
} 


\section{CONCLUSIONS}

The geographical distribution of Japanese investments in the 1980's demonstrates the importance of agglomeration economies in location decisions. Our estimates suggest that a state which experiences a 10 percent increase in any of our agglomeration measures increases its probability of future selection by 5 to 7 percent. This finding emerges even when we control for state effects, state time trends, and industry-level stocks and flowg of U.S. investment. Japanese investors prefer to site their plants in areas where they find concentrations of previous Japanese investments in the same industry and, for auto-related firms, the previous investments made by keiretsu affiliates. These results do not arise through deliberate selection of industries thought to exhibit agglomeration effects. Instead, they figure prominently in a sample including a diverne set of industries. Even the exclusion of heavily localized industries such as autor and sawmills does not alter the basic findings. In addition, we confirm the hypothesia that state borders do not define the relevant economic boundaries for agglomeration effects; border-state activity has up to two-thirds of the attractive power of in-state activity.

Since Japan-specific agglomeration appears to exert a strong influence on location decisions, it suggests that neither natural resources nor specialized labour drive location choice by themselves. This is because those factors should be captured in the pattern of U.S. eatublishment agglomeration. Hence, the finding of strong attraction between Japanese firms points towards the importance of explanations involving intermediate inputs and pure technological spillovern.

In 1985 Kentucky offered an incentive package in excess of $\$ 300$ million to attract a Toyota manufacturing plant. While states do not extend such massive packages frequently, subatantial efforts to lure manufacturing investments are common. The question arisen whether the renults in this paper provide a rationale for policies of this kind. Agglomeration effects imply that any benefits received from attracting a single investment will be magnified by an increased 
probability of attracting subsequent similar investments. However, simulation results indicate that this subsequent investment may be small or negligible, especially for states that Japanese investors perceived as relatively unattractive. Furthermore, the winners in bidding wars between state governments may find that the price paid in terms of subsidies and added infrastructure may offset any gain derived from attracting a foreign manufacturer.

\section{A Appendix: The Conditional Logit Model of Location Choice}

This appendix derives the profit function expressed in equation (1) and discusses the restrictiveness of the assumptions that underlie the empirical work.

The following three sets of variables enter the production function.

- Agglomeration Effects: $A_{i}$, Econornic activity in an area that generates positive externalities for nearby firms engaged in sinular activities.

- Infrastructure Measures: $J_{\text {, }}$, Inputs available in fired rupply to all firms located in the state, e.g. highway miles. port capacity, climate, research universities.

- Priced Variable Inputs: $X_{i}$, Input whose levels are chosen to minimize costo given the prices that prevail in each state, e.g. skilled and unskilled labor, raw materials, energy.

By assuming that the investor has a production function of the Cobb-Douglas form (where the inputs are defined in the body of the paper), we obtain a final specification that is linear in the parameters and where coefficient estimates can be interpreted as probability elasticities.

$$
q=A_{1}^{a_{1}} \cdots A_{K}^{\alpha_{K}} I_{1}^{\beta_{1}} \cdots I_{L}^{\beta_{L}} X_{1}^{n} \cdots X_{M}^{\eta_{M}} \exp (\mu)
$$

The last term, $\mu$, captures state- and investment-specific heterogeneity in total factor pro- 
ductivity.

Define $p$ as the output price, $w_{i}$ as the price of variable input $X_{i}$, and let $\rho \equiv 1-\sum_{i=1}^{M} \gamma_{i}$. If inputs are set to minimize cost, and output is set to equate marginal cost with the output price and $\rho>0$, the profit function is

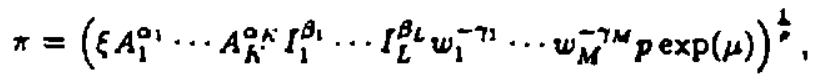

where $\xi$ is a complicated function of the $\gamma_{i}$ parameters.

Taking natural logs and multiplyiug by $\rho$ we obtain

$$
\rho \ln \pi=\ln \xi+\sum_{i=1}^{K} \alpha_{i} \ln A_{i}+\sum_{i=1}^{L} \beta_{i} \ln I_{i}-\sum_{i=1}^{M} \gamma_{i} \ln w_{i}+\ln p+\mu .
$$

This equation specifies profits according to a form amenable to conditional logit estimation as the profit associated with locating plant $j$ in state $s$ is a function of the characteristics of the state. The firm chooses state $s$ if the profits for locating there exceed those associated with alternative locations. We drop $\ln \xi$ from the profitability equation since adding a constant to the profits in each location does not affect the comparison of profits and consequently will not affect choice probabilities.

Assume that infrastructure measures, $I_{i}$, and input prices, $w_{i}$, vary across states (Choices are indexed by $s$ ) but not across investments (Choosers are indexed by $j$ ). In that case, infrastructure variables and input prices can be combined into a single indjcator of the attractiveness of atate s to the "average" (or representative) investor which will be denoted as

$$
\theta_{0} \equiv \sum_{i=1}^{L} \bar{\beta}_{i} \ln I_{i \rho}-\sum_{i=1}^{M} \bar{\gamma}_{i} \ln w_{i o}+\ln \bar{p}_{0}+\bar{\beta}_{0}
$$


where the "upper bar" variables $-\bar{\beta}, \bar{\gamma}, \bar{p}$, and $\bar{\mu}$-are the average of the $N$ Japanese investments.

Now, profitability for investment $j$ in statc $s$ depends on a state effect, the agglomeration activity related to $j$, and an error term.

$$
\rho \ln \pi_{j,}=\theta_{2}+\sum_{i=1}^{K} \alpha_{i} \ln A_{j,}^{i}+\epsilon_{j,}
$$

The error term is defined as follows:

$$
\epsilon_{j \downarrow} \equiv \sum_{i=1}^{\iota}\left(\beta_{i j}-\bar{\beta}_{i}\right) \ln I_{i s}-\sum_{i=1}^{M}\left(\gamma_{i j}-\bar{\gamma}_{i}\right) \ln w_{i 4}+\left(\ln p_{j 4}-\ln \bar{p}_{2}\right)+\left(\mu_{j 0}-\bar{\mu}_{2}\right)
$$

This error term measures deviations from the average Japanese investor's input elasticities, output price, and total factor productivity in each state. The divergences from the average input elasticities are weighted by the corresponding factor price or infrastructure level in that stace. If this error term is distributed as a Type I Extreme Value independent random variable, the parameters in equation (7) can be estimated using conditional logit.

We have assumed Cobb-Douglas production functions and a Type I Extreme Value error term, we believe our results will hold up under more general conditions. With respect to the production function. the Cobb-Douglas form is convenient because it yields a multiplicative pro6t function. However, our specification would remain appropriate in other forms as long as the probt function can be expressed as

$$
\pi_{j,}=g\left(\mathbf{W}_{*}, \mathbf{I}_{4}\right) h\left(\mathbf{A}_{j}\right) \exp \left(\epsilon_{j}\right)
$$

where $g()$ and $h()$ are functions of the input prices, infrastructure and agglomeration variables: $W, I$, and $A$. In that case. the state effect, $\theta$, in equation (2) will be an estimate of $\ln g\left(W_{2}, I_{0}\right)$ 
and $\sum_{i=1}^{K} \alpha_{i} \ln A_{j}^{\prime}$, will correspond to a first-order logarithmic approximation of an arbitrary continuous function $h\left(\mathbf{A}_{\mathbf{j}}\right)$.

With respect to the etror term, McFadden (1974) has demonstrated that the extreme value distribution, $F\left(\epsilon_{j s}\right)=\exp \left(-\exp \left(-\epsilon_{j s}\right)\right]$, is the only one that will yield the logit form. However, Hausman and Wise (1978) found that the conditional probit, assuming an independent nomal distribution, produces very similar results to the conditional logit. ${ }^{18}$ Since the normal distribution is known to be a good approximation for a number of continuous distributions, this finding suggests the computational gains provided by the conditional logit formulation probably do not cause a major loss in robustness as long as the independence assumption is not violated.

The state-specific time trends are derived in the following manner. Denote the initial (1979) value of infrastructure variable or factor price $i$ in state $s$ as $\Gamma_{s 0}^{i}$ or $w_{s 0}^{i}$. Assume that infrastructure and wages grew (or declined) at constant rates, $\nu^{i}$ and $\eta_{i}^{i}$, during the investment period (1980-1992). Then, for investment $j$ that occurs in year $t, I_{j,}^{i}=I_{0,}^{i} \exp \left(\nu_{j}^{i} t_{j}\right)$, $w_{j}^{i}=w_{0,}^{i} \exp \left(\eta_{j}^{i} t_{j}\right)$. U1der these assumptions, equation (7) becomea

$$
\rho \ln \pi_{j,}=\theta_{\rho 0}+\Delta \theta_{\rho} t_{j}+\sum_{i=1}^{K} \alpha_{i} \ln A_{j,}^{i}+\epsilon_{j \bullet}
$$

where $\Delta \theta_{0} \equiv \sum_{i=1}^{L} \beta_{i} \nu_{a}^{i}+\sum_{i=1}^{M} \gamma_{i} \eta_{j}^{i}$.

\section{REFERENCES}

BARTIK, TIMOTHY J., 1985, "Business Location Decisions in the United States: Detimates of the Effects of Unionization. Taxes and Other Characteristics of States," Joumal of

\footnotetext{
11The intuition behind the Bausman and Wise result in that the difference betwees two Type I Extreme Value erroc terme hes the logistic distribution which resemblen the atandard normal.
} 
Business \& Economic Statistics,3, No. 1, 14-22.

Cartton, Dennis W., 1983 "The Location and Employment Choices of New Firms: An Econometric Model With Discrete and Continuous Endogenous Variables," Review of Economics and Statistics 65, 440-449.

Covghlin, Cletis, Joseph V. Terza. and Vachira Arromdee, 1991, "State Characteristics and the Location of Foreign Direct Investment Within the United States," Review of Economics and Statistics, 675-683.

David, Paul A. And Joshua L. Rosenbloom, 1990" Marshallian Factor Market Externalities and the Dynamics of Industrial Location," Journal of Urban Economice 28, 349-370.

Friedman, Joseph. Daniel A. Gerlowski, and Jonathan Silberman. 1992, "What Attracts Foreign Multinational Corporations? Evidence from Branch Plant Location in the United States." Journal of Regional Science Vol. 32 No. 1, 403-418.

Gerlach, Michael L., 1993, "Economic Organization and Innovation in Japan," Forthcoming in Journal of Economic Behavior and Organization

Glaeser, Edward and hed Kallal. José Scheinkman and andrei Schleifer 1992, "Growth in Cities," Journal of Political Economy 100, no. 6, 1126-1152.

Henderson, J. Vernon, 1986, "Efficiency of Resource Ubage and City Size," Journal of Urban Economics 10, 47-70.

Hausman, Jerry and David Wise, 1978, "A Conditional Probit model for Qualitative Choice: Discrete Decisions Recoguizing Interdependence and Heterogeneous Preferences." Econometrica 46. No. 2, 403-426.

Hausman, Jerry and Daniel MCFadden, 1984, "Specification Teste for the Multinomial Logit Model," Econometrica 52, No. 5, 1219-1240.

Krugman, Paul R., 1991a, "Increasing Returns and Economic Geography," Journal of Political Economy 99, 483-499.

Krugman, Paul R., 1991b, Geography and Trade, Cambridge, MA: The MIT Press.

Luger, Michael I. ANd SUdhir SheTTY, 1985, “ Determinante of Poreign Plant Start-upe in the United States: Leasons for Policymakers in the Southeast", Vanderbilt School of Trangnational Law 18, 223-245.

Marshall, Alfred, 1920, Principles of Economice, 8th ed., London: MecMillan.

MCFAdden, DAniel, 1974, "Conditional Logit Adalysis of Qualitative Choice Behaviour," in ZAREM BKA, P., ed., Frontiers in Econometrice, New York: Academic Preas, 105-142.

Rotemberg, J. AND G. SAlONER, 1990, "Competition and Human Capital Accumulation: A Theory of Interregional Specialization and Trade," NBER Working Paper \#3228.

Schmenner, Roger W., Joel C. Huber, and Randall L. Cook, 1987, "Geographic Differences and the Location of New Manufacturing Facilities," Journal of Urben Economice 21, 83-104. 
Smith. Donald and Richard Florida, 1992, "Agglomeration and Industry Location: An Econometric Analysis of Japanese-Afiliated Manufacturing Establishments in AutomotiveRelated Industries, ${ }^{n}$ H. John Heinz III School of Public Policy and Management (Carnegie Mellon University) Working Paper.

Train, Kenneth, 1985, Qualitative Choice Analysis: Theory, Econometrics, and an Application to Automobile Demand, Cambridge, MA: The MIT Press.

WhEELER, DAvid AND AshoKa MOdY, 1992, "International Investment Location Decisions: The Case of U.S. Firms," Journal of International Economics 33, 57-76.

Woodward, Douglas P., 1992, "Locational Determinants of Japanese Manufacturing Startups in the United States", Southern Economic Journal, January, 690-708. 